\title{
PENERAPAN PEMBELAJARAN KOOPERATIF TIPE TWO STAY TWO STRAY (TS-TS) UNTUK MENINGKATKAN HASIL BELAJAR BAHASA INGGRIS SISWA KELAS X SMA NEGERI 9 BULUKUMBA
}

\author{
Nurlaelah ${ }^{1}$ \\ SMA Negeri 9 Bulukumba
}

\begin{abstract}
ABSTRAK
Penelitian ini bermaksud untuk mengetahui penerapan pembelajaran Kooperatif Tipe Two Stay Two Stray (TS-TS) dalam Meningkatkan Hasil Belajar Bahasa Inggris Siswa Kelas SMA Negeri 9 Bulukumba dan untuk mengetahui Hasil Belajar Bahasa Inggris Siswa Kelas X SMA Negeri 9 Bulukumba Mattoanging Kabupaten Sinjai dapat meningkat melalui penerapan pembelajaran Kooperatif Tipe Two Stay Two Stray (TSTS). Jenis penelitian ini adalah penelitian tindakan kelas (PTK). Penelitian tindakan kelas (PTK) ini dilalksanakan di SMA Negeri 9 Bulukumba. Adapun subyek penelitian ini adalah siswa kelas X SMA Negeri 9 Bulukumba yang berjumlah sebanyak 35 siswa yang terdiri dari 14 siswa laki-laki dan 21 siswa perempuan. Dalam penelitian tindakan kelas ini, pengumpulan data dilakukan dengan menggunakan instrument: 1) Wawancara; 2) Obeservasi/ pengamatan; 3) Dokumentasi; 4) Tes. Jenis analisis data yang digunakan adalah analisis data kualitatif dan analisis data kuantitatif. Indikator keberhasilan dalam penelitian tindakan kelas ini terdiri dari indicator keberhasilan proses dan indikator keberhasilan hasil. Indikator proses adalah penelitian ini dikatakan berhasil jika 70 persen atau lebih, dari jumlah siswa yang mengikuti proses pembelajaran dengan kategori baik $(B)$. Berdasarkan hasil dan pembahasan penelitian dalam penelitian tindakan kelas (PTK) terhadap peningkatan hasil belajar Bahasa Inggris siswa melalui penerapan pembelajaran kooperatif tipe Two Stay Two Stray (TS-TS) yang dilaksanakan dua siklus, maka peneliti memperoleh kesimpulan, bahwa dengan menerapkan pembelajaran koperatif tipe Two Stay Two Stray (TS-TS) dapat meningkatkan aktivitas dan hasil belajar Bahasa Inggris siswa di kelas X SMA Negeri 9 Bulukumba.
\end{abstract}

Kata kunci: Pembelajaran Kooperatif, Two Stay Two Stray, Hasil Belajar, Bahasa Inggris

\section{PENDAHULUAN}

Sesuai dengan amanat undangundang Republik Indonesia Nomor 20 tahun 2003 tentang Sistem Pendidikan Nasional yang menyatakan bahwa Pendidikan adalah usaha sadar dan terencana untuk mewujudkan suasana belajar dan proses pembelajaran agar peserta didik secara aktif mengembangkan potensi dirinya untuk =memiliki kekuatan spiritual keagamaan, pengendalian diri, kepribadian, kecerdasan, akhlak mulia, serta keterampilan yang diperlukan dirinya, masyarakat, bangsa, dan negara. Dalam hal ini pendidikan adalah suatu proses untuk membantu manusia dalam mengembangkan dirinya sehingga mampu menghadapi segala perubahan dan permasalahan dengan sikap terbuka. Dengan kata lain pendidikan merupakan untuk meningkatkan kualitas pembelajaran agar sumber daya manusia (SDM) pada anak didik dapat meningkat.

Pendidikan juga dapat mencetak manusia menjadi sumber daya manusia yang handal dan terampil di bidangnya.Pendidikan 
sebenarnya merupakan suatu rangkaian peristiwa yang kompleks.Peristiwa tersebut merupakan suatu rangkaian kegiatan komunikasi antar manusia sehingga manusia itu tumbuh sebagai pribadi yang utuh. Selain itu dalam dunia pendidikan, proses belajar mengajar merupakan proses yang bisa diterapkan. Mengajar dan belajar merupakan proses kegiatan yang tidak dapat dipisahkan.

Belajar pada hakikatnya adalah proses interaksi terhadap semua situasi yang ada disekitar individu. Belajar dapat Bahasa Inggrisndang sebagai proses yang diarahkan kepada tujuan dan proses membuat melalui berbagai pengalaman. Pengalaman itu terjadi karena interaksi manusia dengan lingkungannya, baik lingkungan fisik maupun lingkungan sosial manusia melalui secara efisien dan efektif itulah yang disebut dengan pendidikan. Dengan pendidikanlah setiap individu dibekali dengan berbagai pengetahuan , keterampilan, dan keahlian dalam menghadapi tantangan di masa depan.

Pelaksanaan pembelajaran Bahasa Inggris masih kurang menggunakan variasi dalam proses belajar mengajar dan siswa juga bersikap acuh dengan cara guru mengajar yang kadang menggunakan metode pelajaran yang sifatnya informatif. Siswa kebanyakan menerima pelajaran tanpa memahami apa yang telah dipelajarinya. Mereka pada umumnya hanya menghafal apa yang telah dipelajari. Kemampuan menghafal pada umumnya hanya bertahan dalam waktu yang relatif singkat. Kebanyakan siswa hanya menghafal tentang makna yang dipelajari pada saat akan menghadapi ujian. Setelah ujian selesai konsep-konsep yang telah dihafal pada umumnya mulai hilang dan setelah beberapa saat kemudian makna konsep yang telah dihafal menjadi hilang sama sekali. Menyikapi hal tersebut, pentingnya pemahaman dalam pembelajaran Bahasa Inggris sangat dibutuhkan, sehingga siswa mampu menghadapi ujian tanpa dengan hafalan yang nyatanya tidak

Fakultas Keguruan dan Imu Pendidikan Universitas Bosowa Makassar menjamin akan pengetahuan yang dimiliki secara terus-menerus..

Banyak hal yang dapat menyebabkan keluhan dan anggapan dari siswa tersebut, diantaranya sekolah telah dipisahkan dalam kehidupan sehari-hari, cara guru menyajikan materi dan penciptaan suasana proses pembelajaran yang memungkinkan siswa untuk tekun mengikuti pelajaran Bahasa Inggris. Selama ini kebanyakan siswa belajar Bahasa Inggris dengan cara menghafal, bukan memahami, sehingga selang beberapa saat mereka akan lupa. Keterlibatan siswa selama pembelajaran belum optimal sehingga hasil belajar siswa tidak optimal pula. Oleh karena itu, perlu diterapkan model pembelajaran yang efektif, sehingga hasil belajar siswa dapat pula ditingkatkan.

Berdasarkan hasil observasi awal yang dilakukan calon peneliti terungkap bahwa hasil belajar siswa kelas 1 pada pembelajaran Bahasa Inggris berada pada kualifikasi rendah. Melihat situasi ini, setelah calon peneliti mengobservasi lebih lanjut ternyata ada keganjalan yang terjadi sehingga hasil belajar siswa tidak sesuai.Hal ini disebabkan oleh dua faktor yakni dari guru dan faktor dari siswa. Faktor yang bersumber dari guru diantaranya: 1) guru kurang optimal dalam menyampaikan materi, konsep Bahasa Inggris disampaikan secara informatif sehingga siswa bersifat pasif bahkan timbul kejenuhan pada siswa, 2) pelaksanaan kegiatan belajar kurang menyenangkan dan bermakna karena strategi pembelajaran yang diterapkan kurang tepat yakni hanya mengikuti alur memberikan informasi, latihan soal-soal dan pemberian tugas, 3) tidak dilakukannya manajemen kelas sehingga suasana pembelajaran menjadi kurang kondusif.

Faktor yang bersumber dari siswa diantaranya: 1) siswa tidak memiliki keberanian untuk bertanya dan lebih banyak menceritakan masalah pelajaran kepada teman, 2) siswa menerima materi pelajaran 
secara pasif, siswa hanya mendengarkan materi yang disampaikan oleh guru, 3) kurangnya interaksi dengan guru dan siswa lain, 4) siswa menganggap bahwa pelajaran Bahasa Inggris adalah pelajaran yang membosankan sehingga tidak antusias dalam mengikuti pelajaran dan memilih mengerjakan aktivitas lain seperti ribut, mengganggu siswa lainnya, berjalan didalam kelas sehingga suasana kelas menjadi kurang kondusif untuk belajar. Hal ini sangat mempengaruhi proses belajar dan hasil belajar siswa yang terlihat dalam nilai ulangan harian.

Menyadari belum optimalnya kemampuan siswa dalam pembelajaran Bahasa Inggris yang ditandai dengan rendahnya evaluasi hasil belajar siswa, menuntut guru melakukan perbaikan pembelajaran, agar kemampuan siswa terhadap pembelajaran Bahasa Inggris meningkat sesuai dengan tingkat keberhasilan yang diharapkan. Dalam proses pembelajaran Bahasa Inggris sebagian guru kurang menerapkan metode yang bervariasi sehingga siswa menjadi pasif dalam pembelajaran dan kemampuan dalam berbicara baik dalam mengemukakan pendapat dan bertanya belum mampu dimaksimalkan oleh siswa. Oleh karena itu diperlukan metode pembelajaran yang lebih inovatif yang mampu meningkatkan interaksi baik antara guru dengan siswa maupun antara siswa yang satu dengan siswa lainnya.Selain itu guru juga kurang menerapkan model pembelajaran kooperatif. Salah satu pembelajaran yang melibatkan peran aktif siswa adalah model pembelajaran kooperatif. Pembelajaran kooperatif muncul dari konsep bahwa siswa akan lebih menemukan dan memahami konsep yang sulit jika mereka saling berdiskusi dengan temannya. Ketika siswa bekerja sama untuk menyelesaikan tugas kelompok, mereka seringkali berusaha untuk memberikan informasi, dorongan, atau anjuran pada teman satu kelompoknya yang membutuhkan bantuan. Siswa pada umumnya cenderung lebih sadar pada masalah yang tidak dBahasa Inggrishami oleh siswa lain, sehingga dapat membantu mereka agar focus pada hal-hal yang relevan dengan masalah tersebut, mereka seringkali dapat menjelaskan masalah itu dengan cara yang mereka pahami. Model pembelajaran Two Stay Two Stray (TS-TS) dapat diterapkan untuk semua mata pelajaran dan tingkatan umur. Model pembelajaran Two Stay Two Stray (TS-TS) ini memungkinkan setiap kelompok untuk saling berbagi informasi dengan kelompok-kelompok lain.

Penggunaan model pembelajaran kooperatif tipe Two Stay Two Stray (TSTS) merupakan model pembelajaran sederhana tetapi sangat tepat dan relevan untuk digunakan dalam proses pembelajaran Bahasa Inggris yang dianggap baik dalam memecahkan masalah yang terjadi dalam pembelajaran, sehingga dalam setiap pembelajaran menjadi menyenangkan bagi setiap peserta didik, berpikir logis dan kritis, berkomunikasi, bekerjasama dalam memecahkan sebuah masalah dan memiliki keterampilan dalam kehidupan sosial dan kesadaran terhadap nilai-nilai sosial untuk meningkatkan hasil sehingga dapat diterapkan dalam kehidupan sehari-hari di lingkungan sekitar baik secara individu maupun kelompok.

\section{KAJIAN PUSTAKA}

\section{Teori Konstruktivisme}

\section{a. Pengertian Teori Kontruktivisme}

Teori kontruktivisme merupakan suatu teori yang memberikan kebebasan terhadap manusia yang ingin belajar atau mencari kebutuhannya dengan kemampuan untuk menemukan keinginan atau kebutuhannya tersebut dengan bantuan orang lain. Sejalan dengan itu beberapa pendapat para ahli mendefinisikan teori kontrutivisme.

Suyono dkk (2012:105) mendefinisikan konstruktivisme sebagai sebuah filosofi pembelajaran yang dilandasi premis bahwa dengan menrefleksikan pengalaman, 
mengonstruksi pengetahuan pemahaman kita tentang dunia tempat kita hidup. Setiap kita akan menciptakan hukum dan model mental kita sendiri, yang kita pergunakan untuk menafsirkan dan menerjemahkan pengalaman. Belajar, dengan demikian, semata-mata sebagai suatu proses pengaturan mental seorang untuk mengakomodasi pengalaman-pengalaman baru.

$$
\text { Bell dalam Isjoni }
$$

mengemukakan pendapatnya bahwa paham konstrutivisme memandang siswa datang bangku sekolah membawa persiapan mental dan kognitifnya. Artinya, pelajar yang datang kebangku sekolah sudah memiliki konsep awal dari materi yang akan dipelajari, karena mereka mempunyai potensi untuk pembelajaran mandiri terlebih dahulu dari sumber yang ada atau dari pengalaman dalam lingkungan kehidupannya.

Driver dan Bell dalam Suyono dkk (2012:106) mengemukakan karakteristik pembelajaran konstruktivisme sebagai berikut: (i) Siswa tidak memandang Bahasa Inggris sebagai sesuatu yang pasif melainkan memiliki tujuan, (ii) belajar harus mempertimbangkan seoptimal mungkin proses keterlibatan siswa siswa, (iii) pengetahuan bukan sesuatu yang dating dari luar, melainkan dikonstruksi secara personal, (iv) pembelajaran bukanlah transmisi pengetahuan, melainkan melibatkan pengaturan lingkungan situasi belajar, (v) kurikulum bukanlah sekedar hal yang dipelajari, melainkan seperangkat pembelajaran, materi dan sumber.

Berdasarkan uraian diatas dapat disimpulkan bahwa teori konstruktivisme merupakan teori belajar yang menekankan bahwa siswa tidak hanya menerima pengetahuan tetapi menciptakan suatu makna dari apa yang dipelajari.

\section{b. Pembelajaran Kooperatif Sebagai Implementasi Konstruktivisme}

Teori yang mendasari pembelajaran kooperatif adalah teori kontrusktivisme. Menurut Soedjadi dalam Rusman (2013:201) "pada dasarnya pendekatan teori kontruktivisme dalam belajar adalah suatu pendekatan dimana siswa harus secara individual menemukan dan mentranformasikan memeriksa informasi dengan aturan yang ada dan merevisinya bila perlu".

Menurut Vygotsky dalam Suyono dkk (2012:113) mengemukakan bahwa berdasarkan pendekatan konstruktivis sosial, instruktur lebih berperan sebagai fasilitator darBahasa Inggrisda guru menurut pengertian konvensional. Jika seorang guru menyampaikan kuliah/ceramah dedaktis yang menyangkut pokok bahasan, maka fasilitator membantu siswa untuk mengetahui pemahamannya sendiri terhadap pokok bahasan/konten kurikulum.

Dalam paradigma konstruktivisme seperti yang dikemukakan oleh Vygotsky, murid menganggap peranan guru sebagai salah satu sumber pengetahuan dan bukan sebagai seorang yang tahu segala-galanya. Mereka menganggap pengetahuan sebagai sesuatu yang boleh disesuaikan dan boleh berubah. Siswa juga sadar bahwa siswa bertanggung jawab terhadap diri sendiri untuk menggunakan berbagai cara dalarn menyelesaikan masalah. Dalam arti lain, guru berperan sebagai seorang fasilitator dan pembimbing. Guru bertanggung jawab membimbing dan membantu murid mempelajari sesuatu pelajaran dengan bermakna. Guru tidak boleh belajar untuk murid tetapi murid yang membina pemahamannya sendiri.

Umumnya dalam pembelajaran kooperatif lebih menekankan pada pendekatan kontruktivisme. Dengan landasan berpikir, bahwa siswa akan lebih mudah menemukan dan memahami konsep-konsep yang sulit jika siswa saling mendiskusikan masalah tersebut dengan temannya dalam kelompok-kelompok kecil akan terlihat peran siswa yang lebih kompeten. 


\section{Model Pembelajaran Kooperatif Tipe Two Stay Two Stray (TS-TS)}

a. Pengertian Model Pembelajaran Two Stay Two Stray (TS-TS)

Pembelajaran kooperatif terdiri dari beberapa tipe atau model pembelajaran Salah satunya adalah model Two Stay Two Stray(TS-TS) atau dalam bahasa Indonesia diartikan "Dua tinggal dua tamu" yang dikembangkan oleh Spencer Kagan 1992. Metode ini bisa digunakan dalam semua mata pelajaran dan untuk semua tingkatan usia peserta didik. Metode pembelajaran kooperatif ini merupakan sistem pembelajaran kelompok dengan tujuan agar siswa dapat saling bekerjasama, bertanggung jawab, saling membantu memecahkan masalah dan saling mendorong untuk berprestasi. Metode ini juga melatih siswa untuk bersosialisasi dengan baik.

Penggunaan model pembelajaran kooperatif Two Stay Two Stray (TS-TS)akan mengarahkan siswa untuk aktif, baik dalam berdiskusi, tanya jawab, mencari jawaban, menjelaskan dan juga menyimak materi yang dijelaskan oleh teman. Selain itu, alasan menggunakan model pembelajaran Two Stay Two Stray (TS-TS)ini karena terdapat pembagian kerja kelompok yang jelas tiap anggota kelompok, siswa dapat bekerjasama dengan temannya, dapat mengatasi kondisi siswa yang ramai dan sulit diatur saat proses belajar mengajar.

Berangkat dari permasalahan yang dihadapi peneliti didalam kelas, awalnya dalam pembelajaran ini guru menyampaikan materi yang akan dibahas. Setelah kelompok terbentuk guru memberikan tugas berupa permasalahan-permasalahan yang harus mereka diskusikan jawabannya. Setelah diskusi intrakelompok usai, dua orang dari masing-masing kelompok meninggalkan kelompoknya untuk bertamu kepada kelompok yang lain. Anggota kelompok yang tidak mendapat tugas sebagai tamu mempunyai kewajiban menerima tamu dari suatu kelompok. Tugas mereka adalah menyajikan hasil kerja kelompoknya kepada tamu tersebut. Dua orang yang bertugas sebagai tamu diwajibkan bertamu kepada semua kelompok. Jika mereka telah usai menunaikan tugasnya, mereka kembali ke kelompoknya masing-masing. Setelah kembali ke kelompok asal, baik peserta didik yang bertugas bertamu maupun mereka yang bertugas menerima tamu mencocokkan dan membahas hasil kerja yang telah mereka terima.

b. Tujuan Pembelajaran Kooperatif Tipe Two Stay Two Stray (TS-TS)

Dalam model pembelajaran kooperatif ini memiliki tujuan yang sama dengan pendekatan pembelajaran kooperatif lainnya. Siswa di ajak untuk bergotong royong dalam menemukan suatu konsep. Penggunaan model pembelajaran kooperatif Two Stay Two Stray (TS-TS)akan mengarahkan siswa untuk aktif, baik dalam berdiskusi, tanya jawab, mencari jawaban, menjelaskan dan juga menyimak materi yang dijelaskan oleh teman. Selain itu, alasan menggunakan model pembelajaran Two Stay Two Stray ini karena terdapat pembagian kerja kelompok yang jelas tiap anggota kelompok, siswa dapat bekerjasama dengan temannya, dapat mengatasi kondisi siswa yang ramai dan sulit diatur saat proses belajar mengajar.

\section{c. Kelebihan dan Kekurangan dari Model Pembelajaran Two Stay Two Stray (TSTS)}

Setiap model atau metode pembelajaran yang digunakan tentunya memiliki kelebihan dan kekurangan dalam implementasinya. Tak terkecuali dengan pembelajaran kooperatif tipeTwoStay Two Stray (TS-TS).Dampak kelebihan dan kekurangannya dapat dirasakan selama penggunakan model ini di gunakan.

Menurut Huda (2013:140) dalam pelaksanaannya, pembelajaran kooperatif tipe Two Stay Two Stray (TS-TS) memiliki kelebihan, yaitu:

1) Dapat dikombinasikan dengan teknik Kepala Bernomor 
2) Dapat diterapkan untuk semua mata pelajaran dan tingkatan umur

3) Memungkinkan untuk setiap kelompok untuk saling berbagi informasi dengan kelompokkelompok lain

4) Membantu meningkatkan minat dan prestasi belajar siswa

5) Meningkatkan semangat kerjasama siswa

Adapun kekurangan pembelajaran kooperatif tipe Two Stay Two Stray (TS-TS) meliputi : 1) Membutuhkan waktu yang lama; 2) Siswa yang tidak terbiasa belajar kelompok merasa asing dan sulit untuk bekerjasama sehingga siswa cenderung tidak mau belajar dalam kelompok; 3) Bagi guru, membutuhkan banyak persiapan (materi, dana dan tenaga); 4) Guru cenderung kesulitan dalam pengelolaan kelas.

\section{d. Langkah-Langkah Model \\ Pembelajaran Two Stay Two Stray} (TS-TS)

Pembelajaran kooperatif tipe Two Stay Two Stray (TS-TS) adalah salah satu tipe atau model pembelajaran kooperatif yang mudah diterapkan, melibatkan, aktivitas seluruh siswa tanpa harus ada perbedaan status dan melibatkan peran aktif siswa. Aktivitas belajar dalam model pembelajaran kooperatif tipe Two Stay Two Stray (TS-TS) melibatkan pengakuan tim dan tanggung jawab kelompok untuk pembelajaran individu anggota. Model pembelajaran ini juga sama dengan pembelajaran kooperatif lainnya yang memiliki serangkaian kegiatan.

Huda (2013:141) menjabarkan langkahlangkah pembelajaran kooperatif Two Stay Two Stray(TS-TS):

1. Siswa bekerja sama dengan kelompok berempat sebagaimana biasa.

2. Guru memberikan tugas pada setiap kelompok untuk didiskusikan dan dikerjakan bersama.

3. Setelah selesai, 2 anggota dari masing-masing kelompok diminta meninggalkan kelompoknya dan masing-masing bertamu kedua dari kelompok lain.

4. Dua orang yang "tinggal" dalam kelompok bertugas mensharing informasi dan hasil kerja mereka ke tamu mereka.

5. "Tamu" mohon diri dan kembali kekelompok yang semula dan melaporkan apa yang mereka temukan dari kelompok lain.

6. Setiap kelompok lalu membandingkan dan membahas hasil kerja mereka semua

\section{Hasil Belajar}

\section{a. Pengertian Hasil Belajar}

Hasil belajar pada hakikatnya adalah perubahan tingkah laku individu yang relatif menetap sebagai hasil interaksi dengan lingkungan belajar. Tujuan pembelajaran dapat tercapai dengan baik jika hasil belajar sesuai dengan standar yang diharapkan dalam proses pembelajaran tersebut. Hal ini menunjukkan bahwa hasil belajar harus dirumuskan dengan baik untuk dapat dievaluasi pada akhir pembelajaran.

Sudjana (2009:3) mengemukakan pendapatnya mengenai hasil belajar .Hasil belajar siswa pada hakikatnya adalah "perubahan tingkah laku sebagai hasil belajar dalam pengertian yang lebih luas mencakup dalam pengertian yang lebih luas mencakup bidang kognitif, afektif, dan psikomotorik".

Purwanto (2008:46) menyimpulkan hasil belajar adalah perubahan prilaku siswa akibat hasil belajar. Perubahan prilaku disebabkan karena dia mencapai penguasaan atas sejumlah bahan yang diberikan dalam proses belajar mengajar. Pencapaian itu didasarkan atas tujuan pengajaran yang telah ditetapkan.Hasil itu berupa dalam aspek kognitif, afektif maupun psikomotorik.

Howard Kingsley dalam Sudjana (2009:22) membagi 3 macam hasil belajar: “1) Keterampilan dan kebiasaan; 2) Pengetahuan dan pengertian; 3) Sikap dan cita-cita". Pendapat dari Horward Kingsley ini menunjukkan hasil perubahan dari semua 
proses belajar. Hasil belajar ini akan melekat terus pada diri siswa karena sudah menjadi bagian dalam kehidupan siswa tersebut.

Berdasarkan pendapat diatas, dapat disimpulkan bahwa hasil belajar merupakan adanya perubahan dalam kemampuan dan tingkah laku yang berbeda setelah mengikuti proses belajar.

\section{b. Faktor-Faktor yang Dapat Mempengaruhi Hasil Belajar}

Proses belajar tidak mungkin dicapai begitu saja, banyak faktor yang mempengaruhi sehingga seorang anak mampu mencapai hasil atau keberhasilan dalam belajar.

Tim pengembangan kurikulum MKDP (2011:140) secara umum factor yang memengaruhi hasil belajar sebagai berikut:

Ada dua faktor yang mempengaruhi hasil belajar yaitu faktor internal ( faktor-faktor yang ada dalam diri seseorang ) dan faktor ekternal ( faktor-faktor yang berada diluar diri siswa). Faktor-faktor yang mempengaruhi hasil belajar siswa dijabarkan sebagai berikut:

1) Faktor Fsiologis atau Biologis

Faktor fisiologis atau jasmani individu baik bersifat bawaan maupun yang diperoleh dengan melihat, mendengar, struktur tubuh, cacat tubuh, dan sebagainya.

2) Faktor Psikologis

Faktor psikologis baik yang bersifat bawaan maupun keturunan, yang meliputi :

a) Faktor intelektual terdiri atas:

(1) Faktor potensial, yaitu inteligensi dan bakat.

(2) Faktor aktual yaitu kecakapan nyata dan prestasi.

b) Faktor non-intelektual yaitu komponen-komponen kepribadian tertentu seperti sikap, minat, kebiasaan, motivasi, kebutuhan, konsep diri, penyesuaian diri, emosional, dan sebagainya.

3) Faktor kematangan baik fisik maupun psikis.

Fakultas Keguruan dan Imu Pendidikan Universitas Bosowa Makassar
Yang tergolong faktor eksternal yang mempengaruhi hasil belajar siswa ialah:

1) Faktor sosial yang terdiri atas:

a) Faktor lingkungan keluarga.

b) Faktor lingkungan sekolah.

c) Faktor Lingkungan masyarakat.

2) Faktor Budaya seperti: adat istiadat, ilmu pengetahuan dan teknologi, kesenial dan sebagainya.

3) Faktor lingkungan fisik, seperti fasilitas rumah, fasilitas belajar, iklim, dan sebagainya.

4) Faktor spiritual atau lingkungan keagamaan.

\section{METODE PENELITIAN}

Jenis penelitian ini adalah penelitian tindakan kelas (PTK). Penelitian tindakan kelas (PTK) ini dilalksanakan di SMA Negeri 9 Bulukumba. Adapun subyek penelitian ini adalah siswa kelas X SMA Negeri 9 Bulukumba yang berjumlah sebanyak 35 siswa yang terdiri dari 14 siswa laki-laki dan 21 siswa perempuan. Dalam penelitian tindakan kelas ini, pengumpulan data dilakukan dengan menggunakan instrument: 1) Wawancara; 2) Obeservasi/ pengamatan; 3) Dokumentasi; 4) Tes. Jenis analisis data yang digunakan adalah analisis data kualitatif dan analisis data kuantitatif. Indikator keberhasilan dalam penelitian tindakan kelas ini terdiri dari indicator keberhasilan proses dan indikator keberhasilan hasil. Indikator proses adalah penelitian ini dikatakan berhasil jika 70 persen atau lebih, dari jumlah siswa yang mengikuti proses pembelajaran dengan kategori baik (B).

\section{HASIL PENELITIAN DAN PEMBAHASAN}

1. Hasil Penelitian

1. Deskripsi Kegiatan Secara Umum

Pada bab ini dipaparkan data dan hasil penelitian tentang peningkatan hasil belajar siswa dengan menerapkan model pembelajaran kooperatif tipe Two Stay Two Stray (TS-TS) untuk meningkatkan hasil 
belajar Bahasa Inggrissiswa kelas Dalam pelaksanaan tindakan peneliti bertindak sebagai guru (pelaksana pembelajaran dan observer siswa) dan guru mata pelajaranBahasa Inggris kelas $\mathrm{X}$ beritindak sebagai observer peneliti.

Kegiatan awal penelitian ini dimulai pada hari selasa, 28 Desember 2017 dengan melaksanakan observasi (pra penelitian) di SMA Negeri 9 Bulukumba. Dalam kunjungan tersebut peneliti bermaksud untuk menemui Kepala sekolah untuk menyampaikan keinginan melaksanakan Penelitian Tindakan Kelas (PTK) di kelas X pada mata pelajaran Bahasa Inggris. Pada pertemuan tersebut kepala sekolah memberikan izin pelaksanaan penelitian dan mempersilahkan berkonsultasi langsung dengan guru mata pelajaranBahasa Inggris kelas X untuk mendiskusikan rencana penelitian. Kegiatan selanjutnya peneliti melakukan diskusi singkat dengan guru mata pelajaran Bahasa Inggris, selain itu peneliti mengambil data nilai hasil ulangan tes harian siswa pada mata pelajaran Bahasa Inggris.

Sebelum pelaksanaan tindakan, peneliti mengadakan tes awal yang telah dilakukan pada tanggal 20 Januari 2018 untuk mengetahui sejauhmana pengenalan siswa terhadap pokok bahasan kebijakan pemerintah dalamBahasa Inggris.

Tes awal yang dilakukan diperoleh hasil sebagai berikut :

Tabel 1 Data Hasil Tes Awal Siswa Kelas 2

34

Negeri 9 Bulukumba

\begin{tabular}{ccccc}
\multicolumn{5}{c}{ Negeri 9 Bulukumba } \\
No & Skor & Kualifikasi & $\begin{array}{c}\text { Jumlah } \\
\text { (Siswa) }\end{array}$ & $\begin{array}{c}\text { Presentase } \\
(\%)\end{array}$ \\
\hline 1 & $85-100$ & $\begin{array}{c}\text { Sangat Baik } \\
\text { (SB) }\end{array}$ & 0 & 0,00 \\
2 & $70-84$ & Baik (B) & 4 & 11,43 \\
3 & $55-69$ & Cukup (C) & 12 & 34,29 \\
4 & $46-54$ & $\begin{array}{c}\text { Kurang (K) } \\
\text { Sangat }\end{array}$ & 5 & 14,29 \\
5 & $0-45$ & $\begin{array}{c}\text { Kurang } \\
\text { (SK) }\end{array}$ & 14 & 40,00 \\
\hline \multicolumn{2}{c}{ Jumlah } & & $\mathbf{3 5}$ & $\mathbf{1 0 0 , 0}$ \\
\hline
\end{tabular}

\begin{tabular}{cc}
\hline $\begin{array}{c}\text { Nilai Rata- } \\
\text { rata kelas }\end{array}$ & $\mathbf{4 8 , 2 3}$ \\
\hline Ketuntasan & $\mathbf{1 1 , 4 3 \%}$ (Sangat \\
& Kurang) \\
\hline
\end{tabular}

Sumber: Hasil analisis 2018

Berdasarkan tabel 4.1 menunjukkan bahwa tidak ada siswa memperoleh nilai (85100 ), sebanyak 4 siswa memperoleh nilai (70-84) dengan presentase siswa 5,71 persen, sebanyak 12 siswa dengan presentase 34,29 persen memperoleh nilai (55-69) dengan kualifikasi Cukup (C), sebanyak 5 siswa dengan presentase 14,29 persen memperoleh nilai (46-54) dengan kualifikasi kurang (K) dan sebanyak 14 siswa memperoleh nilai (045) dengan presentase 40,0 persen kualifikasi sangat kurang (SK). Jadi secara klasikal siswa yang mencapai ketuntansan dalam tes awal dengan presentase 11,43 persen sedangkan indicator keberhasilan yang ingin dicapai adalah 70 persen, dan nilai rata-rata siswa 48,23 sedangkan indikator keberhasilan hasil belajar adalah $\leq 70$ dengan demikian pengetahuan siswa sebelum tindakan dalam kualifikasi kurang (K).

Deskripsi proses penelitian tindakan kelas ini terdiri dari dua siklus. Setiap siklus dilaksanakan dalam dua kali pertemuan, dengan alokasi waktu setiap siklusnya adalah 2 x 45 menit. Adapun tindakan siklus I pertemuan pertama dilaksanakan pada hari Selasa, 28 Januari 2018, pukul 11.00-12.30 dan pertemuan kedua dilaksanakan pada tanggal 4 Februari 2018, pukul 11.00-12.30. sedangkan tindakan Siklus II pertemuan pertama dilaksanakan pada hari Selasa, 18 Februari 2018, dimulai pukul 11.30-12.30 dan pertemuan kedua dilaksanakan pada hari selasa 25 Februari 2018, dimulai pukul 11.00-12.30. Dalam tahapan siklus terjadi empat rangkaian kegiatan antara lain: (1) perencanaan tindakan, (2) pelaksanaan tindakan, (3) observasi, (4) refleksi.

Secara umum deskripsi tentang hasil penelitian ini yaitu, pada siklus I siswa yang berhasil memperoleh nilai $\geq 70$ sebanyak 19 orang dengan presentase ketuntasan belajar 
54,28 persen .Sedangkan pada siklus II siswa yang berhasil memperoleh nilai $\geq 70$ sebanyak 29 orang dengan presentase ketuntasan belajar 82,86 persen sehingga dapat disimpulkan bahwa penelitian ini dikatakan berhasil karena indikator keberhasilan hasil belajar siswa telah dicapai minimal 70 persen dari jumlah siswa telah memperoleh nilai $\geq 70$ dengan kualifikasi (Baik).

\section{Paparan Data Proses dan Hasil Penelitian}

a. Siklus I

1) Perencanaan tindakan

Dalam tahap perencanaan ini peneliti (sebagai guru dalam pelaksanaan tindakan) terlebih dahulu berkomunikasi dengan guru mata pelajaranBahasa Inggriskelas $\mathrm{X}$ demi kelancaran proses pelaksanaan siklus I. Selanjutnya peneliti menyiapkan beberapa hal yang diperlukan selama pelaksanaan tindakan diantaranya peneliti melakukan halhal sebagai berikut :

a) Mencari materi pelajaran di buku paket yang relevan dan buku penunjang/pelengkap lainnya yang berkaitan dengan materi.

b) Menyiapkan rencana pelaksanaan pembelajaran (RPP) dengan menerapkan model pembelajaran kooperatif tipe Two Stay Two Stray (TS-TS) mengambil standar kompetensi Memahami Kebijakan Pemerintah Dalam Bidang Bahasa Inggris dengan kompetensi dasarnya adalah Mendeskripsikan perbedaan antara Bahasa Inggris mikro dan makro, Sedangkan indikatornya adalah (1). Mendeskripsikan pengertian ilmu Bahasa Inggris, (2) Menjelaskan secara singkat lahirnya teori Bahasa Inggris mikro dan teori Bahasa Inggris makro dan , (3). Mendeskripsikan perbedaan antara Bahasa Inggrismikro dan Bahasa Inggris makro, (4) Memberikan contoh dimasyarakat tentang Bahasa Inggris mikro dan Bahasa Inggris mikro, dan
(5) Mendeskripsikan peran dan fungsi pemerintah dalam bidang Bahasa Inggris. Adapun tujuan pembelajarannnya diuraikan peneliti adalah siswa dapat (1). Menjelaskan pengertian ilmu Bahasa Inggris, (2) Menjelaskan secara singkat lahirnya teoriBahasa Inggrismikro dan teoriBahasa Inggrismakro, (3). Mendeskripsikan perbedaan antaraBahasa Ing grismikro danBahasa Inggrismakro. (4) Memberikan contoh dimasyarakat tentangBahasa Inggrismikro danBahasa Inggrismikro, dan (5) Mendeskripsikan peran dan fungsi pemerintah dalam bidang Bahasa Inggris. (lampiran 3).

c) Menyiapkan Lembar Kerja Kelompok (LKK) untuk masing-masing kelompok.

d) Menyiapkan lembar observasi untuk guru dan siswa.

2) Pelaksanaan tindakan

Siklus I pertemuan pertama dilaksanakan pada hari selasa, 28 Januari 2018 dan pertemuan kedua pada hari selasa, 4 Februari 2018 pukul 11.00-12.30 WITA. Kegiatan awal berlangsung selama 15 menit. (1) Memberi salam, berdoa, mengecek kehadiran siswa dan pengelolaan kelas, (2) Guru menyampaikan tujuan pembelajaran dan materi pembelajaran, (3) Guru menyampaikan secara umum materi tentang kebijakan pemerintah dalam bidangBahasa Inggrisdan, (4) Menjelaskan langkah-langkah kegiatan yang akan dilakukan siswa dengan menggunakan model pembelajaran Two Stay Two Stray (TS-TS).

Kegiatan inti berlangsung selama 65 menit. Berdasarkan langkah-langkah pembelajaran kooperatif tipe Two Stay Two Stray (TS-TS) guru melaksanakan beberapa tahap yaitu (1) Pembagian kelompok yang terdiri dari 4 orang satu kelompok. Dalam tahap ini guru melaksanakan beberapa kegiatan berikut ini : guru membagi siswa ke dalam 9 kelompok yang beranggotakan 4 
orang siswa. Guru membagi siswa kedalam kelompok berdasarkan jenis kelamin, kemampuan siswa yang dinilai berdasarkan hasil akademis yang diperoleh dari data nilai hasil awal siswa sebelumnya yang terdiri atas siswa yang berkemampuan tinggi, sedang, dan rendah namun karena jumlah siswa yang ganjil maka terdapat satu kelompok yang beranggotakan 3 orang. Setelah itu guru menjelaskan di depan kelas langkah-langkah pembelajaran kooperatif tipe Two Stay Two Stray (TS-TS). (2) Guru memberikan tugas Lembar Kerja Kelompok (LKK) pada setiap kelompok. Dalam tahap ini guru membagikan Lembar Kegiatan Kelompok (LKK) siklus I pertemuan pertama kepada setiap kelompok yang berisi masalahmasalah dalam bentuk pertanyaan tentang materi pokok perbedaanBahasa Inggrismikro danBahasa Inggrismakro. Hasil kerja LKK tersebut dinilai dan dijumlah sebagai nilai kelompok untuk masing-masing kelompok. (3) Siswa bekerjasama menyelesaikan tugasnya. Setelah masing-masing kelompok mendapatkan tugas, kemudian guru mengarahkan siswa untuk bekerja sama dalam menjawab pertanyaan dengan anggota kelompoknya masing-masing. Dalam tahap ini terjadi diskusi dalam kelompok masingmasing dengan durasi yang disediakan selama 20 menit. (4) Setelah semua kelompok selesai, dua anggota dari masingmasing kelompok diminta meninggalkan kelompoknya dan bertamu ke kelompok lain untuk menganalisa hasil pekerjaan kelompok lain. (5) Dua orang yang tinggal dalam kelompok bertugas memberikan informasi hasil kerja ke tamu mereka. Dalam tahap ini, dua orang siswa yang tinggal di kelompok bertugas untuk memberikan informasi tentang hasil pekerjaan mereka kepada anggota kelompoknya. Hasil temuan dari kelompok lain dicatat pada lembar kerja yang telah dibagikan oleh guru. (6) Setelah mendapat info dari kelompok lain, tamu mohon diri dan kembali ke kelompoknya dan melaporkan hasil temuan mereka. Setiap kelompok membandingkan dan membahas hasil pekerjaan mereka dengan hasil temuan mereka pada kelompok lain. (7) Masingmasing kelompok mempresentasekan hasil diskusinya. (8) Diskusi klasikal. Kegiatan ini meberikan kesempatan kepada siswa untuk menganggapi dan bertanya.

Kegiatan akhir berlangsung selama 15 menit. (1) Guru membimbing Siswa untuk memberikan kesimpulan tentang materi pokok perbedaanBahasa Inggrismikro danBahasa Inggrismakro. Pada akhir pembelajaran siklus I pertemuan kedua, guru menyampaikan akan memberikan tes evaluasi yang akan dilaksanakan pertemuan selanjutnya. (4) Guru memberikan pesanpesan moral kepada siswa dan memberikan salam penutup.

3) Observasi dan Evaluasi

Dalam mempermudah proses penelitian, peneliti menggunakan intrumen lembar observasi yang terdiri dari lembar observasi aktivitas guru dan lembar observasi siswa.

a) Siklus I Pertemuan 1

(1) Hasil observasi terhadap kegiatan guru

Data ini diperoleh melalui lembar observasi aktivitas guru selama proses belajar mengajar.

Pada kegiatan awal, guru cukup dalam kegiatan membuka pelajaran, dalam hal ini guru tidak melakukan pengelolahan kelas, guru kurang dalam melakukan apersepsi yang berhubungan dengan materi, guru kurang dalam menyampaikan atau menuliskan tujuan dan materi pembelajaran dan guru kurang dalam menjelaskan langkahlangkah pembelajaran yang akan dilaksanakan.

Pada kegiatan inti, guru baik dalam pembagian kelompok, dalam hal ini guru membagi siswa kedalam kelompok secara adil dan heterogen, guru memberikan Lembar Kerja Kelompok (LKK) sesuai dengan materi dan tujuan pembelajaran yang akan dicapai, pada kegiatan kelompok guru kurang dalam mengarahkan dan membimbing siswa dalam mengerjakan 
tugas, guru tidak memberikan arahan kepada dua siswa yang bertamu dari masing-masing kelompok sebelum bertamu kekelompok lain, guru tidak memberikan bimbingan dan arahan kepada dua siswa yang tinggal dalam memberikan informasi dan hasil kerja mereka kepada tamu, guru kurang dalam memberikan bimbingan kepada setiap kelompok dalam presentase, dan guru kurang memberikan arahan pada saat diskusi klasikal.

Pada kegiatan akhir, guru cukup dalam menyimpulkan materi pembelajaran dan hanya dua siswa yang bersedia memberikan kesimpulan dan guru mengingatkan siswa untuk belajar dan mengucapkan salam penutup.

Berdasarkan penjelasan diatas, maka dapat diketahui bahwa secara keseluruhan aktivitas guru dalam pembelajaran mencapai 58,97 persen dan berada pada kualifikasi kurang (K) sehingga belum mencapai indicator proses yang telah ditetapkan yaitu 70 persen.

(2) Hasil Observasi Aktivitas Siswa

Hasil observasi terhadap aktivitas siswa sesuai kegiatan pembelajaran Two Stay Two Stray (TS-TS) adalah sebagai berikut:

(a) Kegiatan I : Pembagian kelompok yang terdiri dari 4 orang satu kelompok. Dalam tahap ini Pada saat siswa dikelompokkan, suasana kelas menjadi ramai, setelah diarahkan oleh guru suasana kelas dapat dikendalikan,

(b) Kegiatan II : Siswa bekerjasama menyelesaikan tugasnya. Suasana siswa saat melakukan kerja kelompok tampak didominasi oleh anggota kelompok tertentu, sedangkan yang lainnya tampak kurang serius, kurang aktif, dan kurang merespon pertanyaan-pertanyaan.

(c) Kegiatan III: Setelah semua kelompok selesai, dua anggota dari kelompok ditunjuk bertamu diminta meninggalkan kelompoknya dan bertamu ke kelompok lain. Dalam kegiatan ini banyak siswa yang terlihat kebingungan, belum paham maksud bertamu, hanya mendekarkan dan tidak menyampaikan temuan mereka ketika kembali kekelompoknya.

(d) Kegiatan IV: Dua orang yang tinggal dalam kelompok bertugas memberikan informasi hasil kerja ke tamu mereka. Beberapa siswa yang tinggal menjelaskan kepada temannya terlalu cepat sehingga siswa yang bertindak sebagai tamu kurang memahami materi yang diperoleh.

(e) Kegiatan V: Masing-masing kelompok mempresentasekan hasil diskusinya. Presentase kegiatan ini masih terlihat beberapa siswa yang kurang percaya diri terhadap hasil kerja mereka.

Berikut tabel hasil aktivitas belajar siswa selama pembelajaran siklus I pertemuan pertama sebagai berikut:

Tabel 2 Data Hasil Observasi Kegiatan Siswa kelas X SMA Negeri 9 Bulukumba

\begin{tabular}{|c|c|c|c|c|}
\hline No & $\begin{array}{c}\text { Presentase } \\
\text { Keberhasilan }\end{array}$ & Kualifikasi & $\begin{array}{l}\text { Jumlah } \\
\text { (Siswa) }\end{array}$ & $\begin{array}{c}\text { Presentase } \\
(\%)\end{array}$ \\
\hline 1 & $85 \%-100 \%$ & $\begin{array}{c}\text { Sangat } \\
\text { Baik (SB) }\end{array}$ & 5 & 14,29 \\
\hline 2 & $70 \%-84 \%$ & Baik (B) & 7 & 20,00 \\
\hline 3 & $55 \%-69 \%$ & Cukup (C) & 8 & 22,86 \\
\hline 4 & $46 \%-54 \%$ & Kurang (K) & 9 & 25,71 \\
\hline 5 & $0 \%-45 \%$ & $\begin{array}{c}\text { Sangat } \\
\text { Kurang } \\
\text { (SK) }\end{array}$ & 6 & 17,14 \\
\hline & Jumlah & & 35 & 100,00 \\
\hline & Ketuntasan & & \multicolumn{2}{|c|}{$\begin{array}{c}\text { 34,29\% (Sangat } \\
\text { Kurang) }\end{array}$} \\
\hline
\end{tabular}

Berdasarkan tabel 2 diatas maka dapat diketahui bahwa dari keseluruhan kegiatan menunjukkan bahwa 5 siswa dengan presentase 14,29 persen dengan kualifikasi sangat baik, sebanyak 7 siswa dengan presentase 20,00 persen dengan kulifikasi baik (B), sebanyak 8 siswa dengan presentase 22,86 persen dengan kulifikasi cukup (C), sebanyak 9 siswa dengan presentase 25,71 persen dengan kualifikasi kurang dan sebanyak 6 siswa dengan presentase 17,14 
kualifikasi sangat kurang (SK). Sehingga secara keseluruhan observasi aktivitas belajar siswa dalam pembelajaran mencapai 34,29 persen dengan kualifikasi Sangat Kurang (SK). Ini masih sangat jauh dari indikator proses yang ingin dicapai yaitu 70 persen atau lebih dari jumlah siswa mengikuti proses pembelajaran.

c) Siklus I pertemuan kedua

Hal-hal yang diobservasi pada pelaksanaan tindakan siklus I pertemuan kedua adalah cara guru (peneliti) menyajikan materi pelajaran dan aktivitas siswa dalam mengikuti pelajaran apakah sudah sesuai dengan rencana pelaksanaan pembelajaran atau belum.

\section{(1) Hasil Observasi Kegiatan Guru}

Data ini diperolah melaui hasil observasi aktivitas guru selama proses belajar mengajar (Lampiran 11). Pada kegiatan awal, guru cukup dalam kegiatan membuka pelajaran, dalam hal ini guru tidak melakukan pengelolahan kelas, guru melakukan apersepsi yang berhubungan dengan materi, guru dalam menyampaikan atau menuliskan tujuan dan materi pembelajaran dan guru cukup dalam menyampaikan langkahlangkah pembelajaran yang akan dilaksanakan.

Pada kegiatan inti, guru baik dalam pembagian kelompok, dalam hal ini guru membagi siswa kedalam kelompok secara adil dan heterogen, guru memberikan Lembar Kerja Kelompok (LKK) sesuai dengan materi dan tujuan pembelajaran yang akan dicapai, pada kegiatan kelompok guru mengarahkan dan membimbing siswa dalam mengerjakan tugas, guru cukup memberikan arahan kepada dua siswa yang bertamu dari masing-masing kelompok sebelum bertamu kekelompok lain, guru cukup memberikan bimbingan dan arahan kepada dua siswa yang tinggal dalam memberikan informasi dan hasil kerja mereka kepada tamu, guru cukup dalam memberikan bimbingan kepada setiap kelompok dalam presentase, dan guru cukup memberikan arahan pada saat diskusi klasikal.

Pada kegiatan akhir, guru cukup dalam menyimpulkan materi pembelajaran dan hanya dua siswa yang bersedia memberikan kesimpulan dan guru baik dalam memberikan pesan-pesan kepada siswa untuk belajar dan mengucapkan salam penutup. Berdasarkan penjelasan diatas, maka dapat diketahui bahwa secara keseluruhan aktivitas guru dalam pembelajaran mencapai 82,05 persen dan berada pada kualifikasi baik (B)

(2) Hasil Observasi Aktivitas Siswa

Hasil observasi terhadap aktivitas siswa sesuai kegiatan pembelajaran Two Stay Two Stray (TS-TS) (Lampiran12) adalah sebagai berikut:

(a) Kegiatan I : Pembagian kelompok yang terdiri dari 4 orang satu kelompok. Semua siswa tertib dalam pembagian kelompok.

(b) Kegiatan II : Siswa bekerjasama menyelesaikan tugasnya. Suasana siswa saat melakukan kerja kelompok tampak masih didominasi oleh anggota kelompok tertentu, sedangkan yang lainnya tampak kurang serius, kurang aktif, dan kurang merespon pertanyaan-pertanyaan.

(c) Kegiatan III: Dua anggota kelompok ditugaskan bertamu kepada kelompok lain. Dalam kegiatan ini siswa yang ditugaskan untuk bertamu sudah cukup mengerti maksud bertamu, hal ini dilihat dari pemahaman yang mereka jelaskan kepada kelompoknya setelah bertamu.

(d) Kegiatan IV : Dua anggota kelompok yang tinggal menerima tamu dan menjelaskan hasil diskusinya. Pada kegiatan ini siswa menjelaskan hasil diskusi mereka kepada tamu. Lebih baik dari sebelumnya sedikitnya kelompok menyampaikan materi dan hasil kerja mereka dengan jelas sehingga tamu paham terhadap materi yang didapat. 
Namun, Beberapa kelompok masih menjelaskan materi terlalu cepat sehingga "tamu" masih ada kelompok belum paham.

(e) Kegiatan V: Masing-masing kelompok mempresentasekan hasil diskusinya. Presentase kegiatan ini masih terlihat beberapa siswa yang kurang percaya diri terhadap hasil kerja mereka, namun sebagian besar kelompok antusias dalam mempresentasikan hasil diskusinya.

Berikut tabel hasil aktivitas belajar siswa selama pembelajaran siklus I pertemuan kedua :

Tabel 3 Data Hasil Observasi Siswa kelas X SMA Negeri 9 Bulukumba

\begin{tabular}{ccccc}
\hline No & $\begin{array}{c}\text { Presentase } \\
\text { Keberhasilan }\end{array}$ & Kualifikasi & $\begin{array}{c}\text { Jumlah } \\
\text { (Siswa) }\end{array}$ & $\begin{array}{c}\text { Presentase } \\
(\%)\end{array}$ \\
\hline 1 & $85 \%-100 \%$ & $\begin{array}{c}\text { Sangat } \\
\text { Baik (SB) }\end{array}$ & 6 & 17,14 \\
2 & $70 \%-84 \%$ & Baik (B) & 15 & 42,86 \\
3 & $55 \%-69 \%$ & Cukup (C) & 11 & 31,43 \\
4 & $46 \%-54 \%$ & $\begin{array}{c}\text { Kurang (K) } \\
\text { Sangat }\end{array}$ & 1 & 2,86 \\
5 & $0 \%-45 \%$ & $\begin{array}{c}\text { Kurang } \\
\text { (SK) }\end{array}$ & 2 & 5,71 \\
& & & $\mathbf{3 5}$ & $\mathbf{1 0 0 , 0 0}$ \\
\hline \multicolumn{5}{c}{ Kumlah } \\
\multicolumn{4}{c}{ Kumber:Hasil analisis 2018 }
\end{tabular}

Berdasarkan penjelasan diatas maka dapat diketahui bahwa dari keseluruhan kegiatan siswa menunjukkan bahwa 6 siswa dengan presentase 17,14 persen dengan kualifikasi sangat baik, sebanyak 15 siswa dengan presentase 42,86 persen dengan kulifikasi baik (B), sebanyak 11 siswa dengan presentase 31,43 persen dengan kulifikasi cukup (C), hanya 1 siswa dengan presentase 2,86 persen dengan kualifikasi kurang dan hanya 2 siswa dengan presentase 5,71 dengan kualifikasi sangat kurang (SK). Sehingga secara keseluruhan observasi aktivitas belajar siswa dalam pembelajaran mencapai 60,00 persen dengan kualifikasi Cukup (C). Ini masih jauh dari indikator proses yang ingin dicapai yaitu 70 persen atau lebih dari jumlah siswa mengikuti proses pembelajaran dan berhasil melaksanakan seluruh langkah-langkah pembelajaran dalam kualifikasi baik (B).

(3) Hasil Tes Akhir Siklus I

Tes hasil belajar siklus I ini dilaksanakan setelah pelaksanaan tindakan siklus I selesai. Kegiatan ini dilaksanakan pada hari selasa, 11 Februari 2018 pada pukul 11.00-12.00. Waktu yang diberikan selama 60 menit. Hasil tes ini diberikan setelah pertemuan kedua siklus I selesai. Tes ini merupakan salah satu rangkaian kegiatan untuk mengukur sejauh mana materi pelajaran mampu dikuasai siswa.

Hasil belajar siswa tentang materi pokok perbendaan antaraBahasa Inggrismikro danBahasa Inggrismakro dapat dilihat pada tabel sebagai berikut:

Tabel 4 Data Hasil Tes Siklus I kelas X SMA Negeri 9 Bulukumba

\begin{tabular}{|c|c|c|c|c|}
\hline No & Skor & Kualifikasi & $\begin{array}{l}\text { Jumlah } \\
\text { (Siswa) }\end{array}$ & $\begin{array}{c}\text { Presentase } \\
(\%)\end{array}$ \\
\hline 1 & $85-100$ & $\begin{array}{c}\text { Sangat } \\
\text { Baik (SB) }\end{array}$ & 2 & 5,71 \\
\hline 2 & $70-84$ & Baik (B) & 17 & 48,57 \\
\hline 3 & $55-69$ & Cukup (C) & 11 & 31,43 \\
\hline 4 & $46-54$ & Kurang (K) & 3 & 8,57 \\
\hline 5 & $0-45$ & $\begin{array}{c}\text { Sangat } \\
\text { Kurang } \\
\text { (SK) }\end{array}$ & 2 & 5,71 \\
\hline \multicolumn{2}{|c|}{ Jumlah } & & 35 & 100,00 \\
\hline \multicolumn{2}{|c|}{$\begin{array}{l}\text { Nilai rata- } \\
\text { rata kelas }\end{array}$} & \multicolumn{3}{|c|}{66,54} \\
\hline \multicolumn{2}{|c|}{ Ketuntasan } & & \multicolumn{2}{|c|}{$54,28 \%$ (Kurang) } \\
\hline
\end{tabular}

Berdasarkan tabel 4 diatas, maka dapat diketahui hasil tes tindakan siklus I menunjukkan bahwa sebanyak 2 siswa dengan presentase 5,71 persen memperoleh nilai (85-100) denga kualifikasi sangat baik (SB), sebanyak 17 (tujuh belas) siswa dengan presentase 48,57 persen memperoleh nilai (70-84) dengan kualifikasi baik (B), sebanyak 11 siswa dengan presentase 31,43 
persen memperoleh nilai (55-69) kualifikasi cukup (C), sebanyak 3 ( siswa dengan presentase 8,57 persen memperoleh nilai (4654) dengan kualifikasi kurang $(\mathrm{K})$ dan sebanyak 2 siswa dengan presentase 5,71 persen memperoleh nilai (0-45) dengan kualifikasi sangat kurang (SK).

Jadi penguasaan siswa secara klasikal terhadap materi pelajaranBahasa Inggristentang materi pokok perbedaan antaraBahasa Inggrismikro danBahasa Inggrismakro adalah 66,54 dengan ketuntasan klasikal 54,28 persen. Data ini belum sesuai dengan indicator keberhasilan yang ditentukan sebelumnya yaitu 70 persen dari jumlah siswa yang memperoleh nilai $\geq$ 70. Oleh karena itu, peneliti dan guru sepakat melanjutkan ke siklus ke II.

4) Refleksi

Berdasarkan hasil observasi aktivitas dan hasil belajar siswa peneliti dapat menyimpulkan bahwa aktivitas proses dan hasil belajar siswa belum tercapai dengan baik. Kegiatan pembelajaran yang belum dilaksanakan dengan baik oleh guru adalah: guru cukup memberikan arahan kepada dua siswa yang bertamu dari masing-masing kelompok sebelum bertamu kekelompok lain, guru cukup memberikan bimbingan dan arahan kepada dua siswa yang tinggal dalam memberikan informasi dan hasil kerja mereka kepada tamu, guru cukup dalam memberikan bimbingan kepada setiap kelompok dalam presentase, dan guru cukup memberikan arahan pada

saat diskusi klasikal.

Tindakan perbaikan yang harus dilakukan di siklus selanjutnya adalah guru harus berusaha untuk membimbing siswa bekerjasama dalam kelompoknya, membimbing siswa pada saat bertamu kepada kelompok lain dan menjelaskan maksud bertamu, membimbing siswa yang tinggal dalam menjelaskan hasil diskusinya dengan baik pada kelompok tamu, membimbing siswa mempresentasikan hasil

Fakultas Keguruan dan Imu Pendidikan Universitas Bosowa Makassar diskusinya, dan membimbing siswa dalam diskusi klasikal.

Aktivitas siswa, semua kegiatan pembelajaran sesuai dengan langkah-langkah pembelajaran kooperatif tipe Two Stay Two Stray (TS-TS) masih harus ditingkatkan karena semua kegiatan belum terlaksana dengan baik oleh siswa. Jadi kegiatan yang harus ditingkatkan pelaksanaannya oleh siswa dengan bimbingan dan arahan guru adalah berusaha memahami materi yang diberikan, bekerjasama dengan teman kelompoknya, siswa yang tinggal menjelaskan materi dengan baik kepada tamu, lebih percaya diri mempresentasiakan hasil diskusinya dan lebih antusias saat diskusi klasikal.

\section{b. Siklus II}

1) Perencanaan tindakan

Pelaksanaan kegiatan siklus II, peneliti kembali mempersiapkan beberapa yang diperlukan selama pelaksanaan tindakan pembelajaran yaitu :

(a) Mencari materi pelajaran di buku paket yang relevan dan buku penunjang/pelengkap lainnya yang berkaitan dengan materi.

(b) Menyiapkan rencana pelaksanaan pembelajaran (RPP) dengan menerapkan model pembelajaran kooperatif tipe Two Stay Two Stray (TS-TS) mengambil standar kompetensi Memahami Kebijakan Pemerintah Dalam BidangBahasa Inggrisdengan kompetensi dasarnya adalah Mendeskripsikan perbedaan antaraBahasa Inggrismikro dan makro, Sedangkan indikatornya adalah (1). Mendeskripsikan masalahmasalah yang dihadapi pemerintah dalam bidangBahasa Inggrisdan (2) Mengidentifikasi kebijakan pemerintah dalam bidang bidang Bahasa Inggris. Adapun tujuan pembelajarannnya diuraikan peneliti adalah siswa dapat (1) Mendeskripsikan masalah-masalah 
yang dihadapi pemerintah dalam bidangBahasa Inggrisdan

Mengidentifikasi

kebijakan

pemerintah dalam bidang bidang

Bahasa Inggris, (lampiran 16).

(c) Menyiapkan Lembar Kerja Kelompok (LKK) untuk masing-masing kelompok.

(d) Menyiapkan lembar observasi untuk guru dan siswa.

2) Pelaksanaan tindakan

Siklus II pertemuan pertama dilaksanakan pada hari selasa, 18 Januari 2018 dan pertemuan kedua pada hari selasa, 25 Februari 2018 pukul 11.00-12.30 WITA. Kegiatan awal berlangsung selama 15 menit. (1) Memberi salam, berdoa, mengecek kehadiran siswa dan pengelolaan kelas, (2) Guru menyampaikan tujuan pembelajaran dan materi pembelajaran, (3) Guru menyampaikan secara umum pokok bahasan masalah-masalah yang dihadapi pemerintah dalam bidangBahasa Inggrisdan kebijakan pemerintah dalam bidang Bahasa Inggris, (4) Menjelaskan langkah-langkah kegiatan yang akan dilakukan siswa dengan menggunakan model pembelajaran Two Stay Two Stray (TS-TS).

Kegiatan inti berlangsung selama 65 menit. Berdasarkan langkah-langkah pembelajaran kooperatif tipe Two Stay Two Stray (TS-TS) guru melaksanakan beberapa tahap yaitu (1) Pembagian kelompok yang terdiri dari 4 orang satu kelompok. Dalam tahap ini guru melaksanakan beberapa kegiatan berikut ini : guru membagi siswa ke dalam 9 kelompok yang beranggotakan 4 orang siswa. Guru membagi siswa kedalam kelompok berdasarkan jenis kelamin, kemampuan siswa yang dinilai berdasarkan hasil akademis yang diperoleh dari data nilai hasil awal siswa sebelumnya yang terdiri atas siswa yang berkemampuan tinggi, sedang, dan rendah namun karena jumlah siswa yang ganjil maka terdapat satu kelompok yang beranggotakan 3 orang. Setelah itu guru menjelaskan kembali di depan kelas langkah- langkah pembelajaran kooperatif tipe Two Stay Two Stray (TS-TS). (2) Guru memberikan tugas Lembar Kerja Kelompok (LKK) pada setiap kelompok. Dalam tahap ini guru membagikan Lembar Kegiatan Kelompok (LKK) kepada setiap kelompok yang berisi masalah-masalah dalam bentuk pertanyaan tentang pokok bahasan masalahmasalah yang dihadapi pemerintah dalam bidang Bahasa Inggris.. (3) Siswa bekerjasama menyelesaikan tugasnya. Setelah masing-masing kelompok mendapatkan tugas, kemudian guru mengarahkan siswa untuk bekerja sama dalam menjawab pertanyaan dengan anggota kelompoknya masing-masing. Dalam tahap ini terjadi diskusi dalam kelompok masingmasing dengan durasi yang disediakan selama 15 menit. (4) Setelah semua kelompok selesai, dua anggota dari masingmasing kelompok diminta meninggalkan kelompoknya dan bertamu ke kelompok lain untuk menganalisa hasil pekerjaan kelompok lain. (5) Dua orang yang tinggal dalm kelompok bertugas memberikan informasi hasil kerja ke tamu mereka. Dalam tahap ini, dua orang siswa yang tinggal di kelompok bertugas untuk memberikan informasi tentang hasil pekerjaan mereka kepada anggota kelompoknya. Hasil temuan dari kelompok lain dicatat pada lembar kerja yang telah dibagikan oleh guru. (6) Setelah mendapat info dari kelompok lain, tamu mohon diri dan kembali ke kelompoknya dan melaporkan hasil temuan mereka. Setiap kelompok membandingkan dan membahas hasil pekerjaan mereka dengan hasil temuan mereka pada kelompok lain. (7) Masingmasing kelompok mempresentasekan hasil diskusinya. (8) Diskusi klasikal. Kegiatan ini meberikan kesempatan kepada siswa untuk menganggapi dan bertanya.

Kegiatan akhir berlangsung selama 15 menit. (1) Guru membimbing siswa untuk memberikan kesimpulan tentang materi pokok kebijakan pemerintah dalam bidang Bahasa Inggris. Pada akhir pembelajaran 
siklus II pertemuan kedua, guru menyampaikan akan memberikan tes evaluasi yang akan dilaksanakan pertemuan selanjutnya. (4) guru memberikan pesanpesan moral kepada siswa dan memberikan salam penutup.

3) Observasi dan Evaluasi

Dalam mempermudah proses penelitian, peneliti menggunakan intrumen lembar observasi yang terdiri dari lembar observasi aktivitas guru dan lembar observasi siswa.

a) Hasil observasi terhadap kegiatan guru

Data ini diperoleh melalui lembar observasi aktivitas guru selama proses belajar mengajar.

Pada kegiatan awal, guru membuka pelajaran dengan baik, guru baik dalam menyampaikan apersepsi yang berhubungan dengan materi, guru kurang dalam menyampaikan atau menuliskan tujuan dan materi pembelajaran dan guru menjelaskan dengan baik langkah-langkah pembelajaran yang akan dilaksanakan.

Pada kegiatan inti, guru membagi kelompok dengan baik, dalam hal ini guru membagi siswa kedalam kelompok secara adil dan heterogen, guru memberikan Lembar Kerja Kelompok (LKK) sesuai dengan materi dan tujuan pembelajaran yang akan dicapai, pada kegiatan kelompok guru mengarahkan dan membimbing siswa dalam mengerjakan tugas, guru memberikan arahan dengan baik kepada dua siswa yang bertamu dari masing-masing kelompok sebelum bertamu kekelompok lain, guru memberikan bimbingan dan arahan dengan baik kepada dua siswa yang tinggal dalam memberikan informasi tentang hasil kerja mereka kepada tamu, guru masih kurang dalam memberikan bimbingan kepada setiap kelompok dalam presentase, dan guru memberikan arahan pada saat diskusi klasikal dengan baik. Pada kegiatan akhir, guru cukup dalam menyimpulkan materi pembelajaran dan tiga siswa yang bersedia memberikan kesimpulan dan guru mengingatkan siswa untuk belajar dan mengucapkan salam penutup.
Berdasarkan penjelasan diatas, maka dapat diketahui bahwa secara keseluruhan aktivitas guru dalam pembelajaran mencapai 97,4 persen dan berada pada kualifikasi sangat baik (SB)

b) Hasil Observasi Terhadap Kegiatan Siswa

Hasil observasi terhadap aktivitas siswa sesuai kegiatan pembelajaran Two Stay Two Stray (TS-TS) adalah sebagai berikut:

(1) Kegiatan I : Pembagian kelompok yang terdiri dari 4 orang satu kelompok. Semua kelompok tertib membentuk kelompok .

(2) Kegiatan II : Pemberian lembar kerja kelompok (LKK) pada setiap kelompok. Masing-masing kelompok menerima dan menyelesaikan tugas yang diberikan dengan baik.

(3) Kegiatan III : Dua anggota dari kelompok "bertamu" kekelompok lain. Siswa yang bertamu memperoleh hasil yang mereka harapkan. Sehingga pada saat kembali bergabung dengan kelompoknya siswa menyimpulkan hasil kerja mereka dengan baik.

(4) Kegiatan IV : Dua anggota kelompok yang "tinggal" menerima tamu dan menjelaskan hasil diskusinya. Pada kegiatan ini siswa menjelaskan hasil diskusi mereka kepada tamu dengan baik.

(5) Kegiatan V : Masing-masing kelompok mempresentasekan hasil diskusinya. Presentase kegiatan ini masih sebagian besar kelompok antusias dalam mempresentasikan hasil diskusinya, hanya saja satu kelompok kurang percaya diri untuk mempresentasikan hasil diskusinya.

Berikut tabel hasil aktivitas belajar siswa selama pembelajaran siklus II sebagai berikut: 
Tabel 5 Hasil Observasi Kegiatan siswa Kelas X SMA Negeri 9 Bulukumba

\begin{tabular}{|c|c|c|c|c|}
\hline No & $\begin{array}{c}\text { Presentase } \\
\text { Keberhasilan }\end{array}$ & Kualifikasi & $\begin{array}{l}\text { Jumlah } \\
\text { (Siswa) }\end{array}$ & $\begin{array}{c}\text { Presentase } \\
(\%)\end{array}$ \\
\hline 1 & $85 \%-100 \%$ & $\begin{array}{c}\text { Sangat } \\
\text { Baik (SB) }\end{array}$ & 25 & 71,43 \\
\hline 2 & $70 \%-84 \%$ & Baik (B) & 4 & 14,43 \\
\hline 3 & $55 \%-69 \%$ & Cukup (C) & 6 & 17,14 \\
\hline 4 & $46 \%-54 \%$ & Kurang (K) & 0 & 0,00 \\
\hline 5 & $0 \%-45 \%$ & $\begin{array}{c}\text { Sangat } \\
\text { Kurang } \\
(\mathrm{SK})\end{array}$ & 0 & 0,00 \\
\hline & Jumlah & & 35 & 100,00 \\
\hline & Ketuntasan & & \multicolumn{2}{|c|}{ 82,86\% (Baik) } \\
\hline
\end{tabular}

Berdasarkan table 5 diatas maka dapat diketahui bahwa dari keseluruhan kegiatan menunjukkan bahwa sebanyak 24 siswa dengan presentase 71,43 persen dengan kualifikasi sangat baik, sebanyak 5 dengan presentase 14,43 persen dengan kulifikasi baik (B), sebanyak 6 siswa dengan presentase 17,14 persen dengan kulifikasi cukup (C), tidak ada dengan kualifikasi kurang dan tidak siswa dengan kualifikasi sangat kurang (SK). Sehingga secara keseluruhan observasi aktivitas belajar siswa dalam pembelajaran mencapai 82,86 persen dengan kualifikasi Baik (B), mencapai indikator proses yang telah ditentukan.

c) Hasil Tes Akhir Siklus II

Tes hasil belajar siklus II ini dilaksanakan pada hari selasa, 25 Februari 2018 pada pukul 12.30-13.30. Waktu yang disediakan selama 60 menit. Hasil tes ini diberikan setelah pertemuan kedua siklus II selesai. Tes ini merupakan salah satu rangkaian kegiatan untuk mengukur sejauh mana materi pelajaran mampu dikuasai siswa. Hasil belajar siswa tentang materi pokok malasah-masalah yang dihadapi pemerintah dalam bidangBahasa Inggris dilihat pada tabel sebagai berikut:

Fakultas Keguruan dan Imu Pendidikan Universitas Bosowa Makassar
Tabel 6 Data Hasil Belajar Siklus II kelas X SMA Negeri 9 Bulukumba

\begin{tabular}{|c|c|c|c|c|}
\hline No & Skor & Kualifikasi & $\begin{array}{l}\text { Jumlah } \\
\text { (Siswa) }\end{array}$ & $\begin{array}{c}\text { Presentase } \\
(\%)\end{array}$ \\
\hline 1 & $85-100$ & $\begin{array}{c}\text { Sangat } \\
\text { Baik (SB) }\end{array}$ & 17 & 48,57 \\
\hline 2 & $70-84$ & Baik (B) & 12 & 34,29 \\
\hline 3 & $55-69$ & Cukup (C) & 6 & 17,14 \\
\hline 4 & $46-54$ & Kurang (K) & 0 & 0,00 \\
\hline 5 & $0-45$ & $\begin{array}{c}\text { Sangat } \\
\text { Kurang } \\
\text { (SK) }\end{array}$ & 0 & 0,00 \\
\hline \multicolumn{2}{|c|}{ Jumlah } & \multicolumn{3}{|c|}{35} \\
\hline \multicolumn{2}{|c|}{$\begin{array}{l}\text { Nilai rata- } \\
\text { rata kelas }\end{array}$} & \multicolumn{3}{|c|}{80,71} \\
\hline \multicolumn{2}{|c|}{ Ketuntasan } & & \multicolumn{2}{|c|}{$82,86 \%$} \\
\hline
\end{tabular}

Sumber: Hasil analisis 2018

Berdasarkan tabel 6 diatas, maka dapat diketahui hasil tes tindakan siklus II menunjukkan bahwa sebanyak 17 siswa dengan presentase 48,57 persen memperoleh nilai (85-100) denga kualifikasi sangat baik (SB), sebanyak 12 siswa dengan presentase 34,29 persen memperoleh nilai (70-84) dengan kualifikasi baik (B ), sebanyak 6 siswa dengan presentase 17,14 persen memperoleh nilai (55-69) kualifikasi cukup (C), tidak ada siswa memperoleh nilai (4654) dengan kualifikasi kurang $(\mathrm{K})$ dan tidak ada memperoleh nilai (0-45) dengan kualifikasi sangat kurang (SK).

Jadi nilai rata-rata terhadap materi pelajaranBahasa Inggristentang materi pokok masalah-masalah yang dihadapi pemerintah dalam bidangBahasa Inggrisadalah 80,71 dengan ketuntasan klasikal 82,86 persen atau telah sesuai dengan indikator keberhasilan yang ditentukan sebelumnya yaitu 70 persen dari jumlah siswa yang memperoleh nilai $\geq$ 70. Oleh karena itu, peneliti dan guru sepakat menghentikan penelitian.

4) Refleksi

Berdasarkan hasil pelaksanaan penelitian tindakan siklus II secara umum dengan menggunakan pembelajaran kooperatif tipe Two Stay Two Stray (TS-TS), baik hasil tes dan observasi guru dan siswa 
menunjukkan peningkatan. Hal ini disebabkan oleh upaya yang dilakaukan dalam mengatasi kekurangan-kekurangan yang terjadi pada siklus sebelumnya. Dalam hal ini, Siswa menjelaskan dengan baik hasil diskusi mereka dan tidak siswa tidak kesulitan lagi dalam mengerjakan lembar kerja. Kemudian hasil pembelajaran yang telah diterapkan mencapai indikator keberhasilan yang telah ditentukan. Melihat hasil keseluruhan kegiatan pada siklus II dapat disimpulkan bahwa dengan menerapkan pembelajaran kooperatif tipe Two Stay Two Stray (TS-TS) telah dilaksanakan dengan baik oleh guru dan siswa sehingga tidak perlu ada perbaikan dan penelitian bisa dihentikan.

\section{Pembahasan}

Penelitian Tindakan Kelas (PTK) ini terdiri dari II siklus. Penelitian ini berakhir setelah pelaksanaan siklus II yang telah mencapai indikator keberhasilan yang telah ditetapkan. Penerapan pembelajaran kooperatif tipe Two Stay Two Stray (TS-TS) di kelas $X$ pada mata pelajaran Bahasa Inggris tentang memahami kebijakan pemerintah dalam bidang Bahasa Inggris, menjadikan suasana belajar menjadi menyenangkan dan menigkatkan aktivitas belajar siswa. Hal inilah yang kemudian memberikan hasil signifikan terhadap hasil belajar Bahasa Inggris siswa.

Tingkat pencapaian siswa terhadap hasil belajar sudah cukup optimal, sebagaimana kriteria keberhasilan yang telah ditetapkan adalah setiap siswa harus memperoleh $\geq 70$. Berdasarkan hasil belajar Bahasa Inggris siswa menunjukkan bahwa pada pelaksanaan siklus I yakni penguasaan klasikal mencapai 66,54 dan ketuntasan klasikal mencapai 54,28 persen, hasil observasi guru dan siswa diperoleh 82,05 dan 60,00 persen. Sedangkan pada pelaksanaan siklus II penguasaan klasikal siswa 80,71 dan ketuntasan klasikal mencapai 82,86 persen, hasil obeservasi guru dan siswa diperoleh ketuntasan klasikal
97,43 persen dan 82,86 persen. Perbedaan nilai hasil belajar dan hasil observasi antara siklus I dan siklus II menunjukkan bahwa pembelajaran kooperatif tipe Two Stay Two Stray (TS-TS) dapat meningkatkan hasil belajar siswa. Hal ini disebabkan pada proses belajar mengajar dengan tipe Two Stay Two Stray (TS-TS), siswa terlibat secara bersama dalam kelompok untuk menyelesaikan lembar kerja kelompok dan kemampuan siswa dalam menjawab pertanyaan yang diberikan oleh guru.

Peningkatan aktivitas dari siklus I ke siklus II disebabkan pada pembelajaran kooperatif tipe Two Stay Two Stray (TS-TS) membentuk siswa belajar keterampilan sosial untuk siswa memiliki banyak kesempatan untuk mengemukakan pendapat dan mengelolah informasi yang didapat serta meningkatkan keterampilan berkomunikasi. Selain itu anggota kelompok juga bertanggung jawab atas keberhasilan kelompoknya. Sejalan dengan teori kontruktivisme yang menyatakan bahwa siswa akan lebih mudah menemukan dan memahami konsep-konsep sulit jika mereka saling mendiskusikan masalah tersebut dengan temannya dalam kelompok kecil. Dari teori tersebut disimpulkan bahwa siswa lebih termotivasi dalam menyelesaikan tugas-tugas kelompok yang ada karena semua siswa tidak hanya bertanggung jawab atas belajarnya tetapi juga teman sekelompoknya, pertanggungjawaban ini dititik beratkan pada aktivitas anggota kelompok yang saling mendukung, saling membantu dan saling bekerja sama sehingga hasil belajar siswa mengalami peningkatan. Berdasarkan penjelasan diatas, peneliti menarik kesimpulan bahwa dengan menerapkan pembelajaran kooperatif tipe Two Stay Two Stray (TS-TS) dapat meningkatkan hasil belajar siswa pada mata pelajaranBahasa Inggris di kelas X. SMA Negeri 9 Bulukumba. 


\section{KESIMPULAN}

Berdasarkan hasil dan pembahasan penelitian dalam penelitian tindakan kelas (PTK) terhadap peningkatan hasil belajar Bahasa Inggris siswa melalui penerapan pembelajaran kooperatif tipe Two Stay Two Stray (TS-TS) yang dilaksanakan dua siklus, maka peneliti memperoleh kesimpulan, bahwa dengan menerapkan pembelajaran koperatif tipe Two Stay Two Stray (TS-TS) dapat meningkatkan aktivitas dan hasil belajar Bahasa Inggris siswa di kelas X SMA Negeri 9 Bulukumba.

\section{DAFTAR PUSTAKA}

Agus Suprijono. (2009). Cooperatif Learning Teori dan Aplikasi PAIKEM. Pustaka Pelajar: Yogyakarta

Aqib, Zainal. (2009). Penelitian Tindakan

Kelas. Yrama Widya: Bandung

Huda, Miftahul. (2013). Cooperative LearningTeknik, Struktur, dan Model Penerapan. Pustaka Pelajar: Yokyakarta.

Isjoni. (2012). Cooperatif Learning Efektifitas Pembelajaran Kelompok. Alfabeta: Bandung

Jupri. (2010). Penerapan Model Pembelajaran Kooperatif Tipe Two Stay-Two Stray (Ts-Ts) Untuk Meningkatkan Motivasi Dan Hasil Belajar Peserta Didik Materi Pokok Segi Empat Kelas VII C Mts Taqwal Ilah Tembalang. Skripsi. Bahasa Inggris. Semarang: Fakultas Tarbiyah Institut Agama Islam Negeri Walisongo.

Lipu dan Tirtaraharja. (2010). Pengantar Pendidikan. UNM: Makassar

Khalik,Abdul. (2009). Penelitian Tindakan Kelas. Pare-pare: FIP UNM

Kunandar. (2012). Langkah Mudah Penelitian Tindakan Kelas Sebagai Pengembangan Profesi Guru. Jakarta: Raja Grafindo Persada.
Purwanto. (2008). Evaluasi hasil belajar. Pustaka Pelajar: Yogyakarta

Rusman. (2013). Model-Model Pembelajaran Mengembangkan Profesionalisme Guru Edisi Kedua. Rajawali Pers: Jakarta.

Sudjana, Nana. (2009). Penilaian Hasil Proses Belajar Mengajar. Rosda: Bandung.

Suyono dan Haryanto. (2012). Belajar dan Pembelajaran Teori dan Konsep. Rosda: Surabaya

Tim Pengembang MKDP Kurikulum dan Pembelajaran. (2011). Kurikulum dan Pembelajaran. Rajawali Pers: Bandung

Trianto. (2009). Mendesain Pembelajaran Inovatif-Progresif.Surabawa: Kencana

Yudhistira, Dadang. (2013). Menulis penelitian Tidakan Kelas Yang Apik. Grasindo: Jakarta 